\title{
Meta-cognitive learning strategies: The effect of training strategies on memorizing, comprehension and the speed of reading
}

\author{
Mohammad Asgari \\ Allameh Tabata'i University, Iran \\ Maryam Rafiee \\ Azad University, Hamedan Branch, Iran
}

\section{Introduction}

Learning subjects is the main aim of education. The increasing advancement of science has resulted in the learning to become remarkable. As the necessity of the effective learning is to use strategies which help the learner to store the information longer (Farmihani, \& Farahani, 1999). Learning strategies help the students to handle different situations of learning more effectively so that they can obtain, store and apply the new knowledge (Wolteres, 2004). Meta cognition is defined as the "thinking about thinking" or "knowing about knowing". Meta cognition can include different shapes; knowledge about when and where to use specific strategies to solve a problem (Shamrock, 2008). The term Meta cognition refers to our knowledge about our own cognitive processes and manner to use them optimally to achieve our learning objectives (Seyf, 2007). In Liee's (2008) studies about learning strategies. He concluded that auto regulation learning strategies influenced the learners' satisfaction from education system and their academic performance. Also, Anderson (2002) reported the effect of auto regulation learning strategies and motivation strategies for learning on the learners' academic success. In a research, entitled the role of Meta cognition in education and learning, Bruce et al (2007), concluded that the application of teaching Meta cognitive skills in second language is highly appreciated. A motivation strategy for learning is the most cognitive knowledge and strategies in reading and its education makes the reading comprehension easy for student. Nijoes, Segers and Giyselers (2008), showed that Meta cognition strategies create deep processing of learning in 
different environments. Based on Goh's (2008) research, teachers are necessary to spread their student's Meta cognition and teach them how to use the effective strategies for different activities. Regarding the interaction of cognitive and motivation factors, the researches show a linear relationship among the motivation factors (self-efficacy and internal value) and auto regulation components (cognitive and metacognitive strategies and resource management), meaning the rate of using meta cognitive strategies increases with the increased feeling of self-efficacy and internal value in students. In fact, the type of student's motivation beliefs influences the learning rate and use of Meta cognitive strategies significantly. Hong et al (2009) reported a significant positive correlation among the motivation dimension, cognitive abilities and accuracy level of self-assessment. The findings showed that self-assessment accuracy has a strong relationship with the level of academic performance. Using Meta cognitive strategies depends on the manner the students are assessed by. Lee (2008) showed that diagnosis and abstract experiences play important role in Meta memory judgment. Lane and Skoog (2003), showed that interest in study field and external motivation, has the strongest relationship with Meta cognitive strategies.

In Coas et al (2004), study it was found out that successful learning in educational environments under the control of language learner based of computer depends on their Meta cognition is of positive motivation factors. In Marcheschiet al (2000), Meta cognition education is considered to be infective in learning language when they are incompatible with students' capacity. Naimieet al (2010), the teaching methods must be proportional with learners' strategies. To help students to organize they believe one of the most outstanding features of meta cognitive skills is that it problems individual's awareness about the current of thoughts and application of their contemplation and helps to generalize the learnt materials in natural situations to solve the problems more effectively. More and press (2001) showed if helped to review his role as an active learner and assess his learning level, he can increase transfer and supervision skill in himself. Yaghobkhani (2010) the more successful students use Meta cognitive and cognitive learning strategies with the girls using these strategies more than boys. Also, metacognitive strategies are more effective in academic success than cognitive ones. Shirley and Larkin (2000), concluded that metacognition does not grow with age, but social environment, teacher's drills, the nature of cognitive problem and emotional states influences the person's Meta cognition. Lee,(2008)In a research, the effects of educating cognitive and meta cognitive strategies on meta problem solving in students with learning problems were studied. Catty and Kriss et al (2001), reported a significant and positive relationship between class scores and Meta cognition and positive propensity in students. Alevenet al (2006),other researchers concluded that the presence of a smart educational system which is based on Meta cognition abilities can help them to be more successful students. Sone (2010), Meta cognition control is a necessary process which must be paid attention to Ranglee (2008) another research showed that the Meta cognitive learning strategies in 
different environments can create deep learning processing. Nes, Midelton(2012) Auto reglation learning is a conceptual model which can be applied to design Meta cognitive learning strategies for disabled students. The results show that this strategy can be effective in more preparation for class, assignment, scores and teacher's perception from student's activities in math classes. Dong et al (2010), the result of ore search showed that effective language learning is related to Meta cognitive learning strategies. Haedek and Song (2001), researched the effect of Meta cognitive strategies education and control resource on the learning of extension. The results showed an interactive relationship between the type of educating Meta cognitive strategies and that of control resource (internal and external).Iwai(2011)in a research about metacognitive strategies of reading students use, the results showed that teachers teach Meta cognitive strategies of reading to students separately. Ersozlu (2010) in another research, the learning and study strategies are shared in all sections but there were some differences in organizational and emotional strategies.

In a research in Iran, the researchers concluded that successful students use Meta cognitive strategies in their language learning (Gerami,Madani, 2011). These strategies are considered to be a tool to activity and self-assessment is of great importance (Lavasani, Faryadres, 2011). The results of surveying Meta cognitive strategies (listening) showed that students were different in awareness of Meta cognitive strategies of listening. In addition, students differ in terms of personal knowledge and translation (Rahimi, Katal, 2011). Marandi and Mokhtarnia (2010) in another research, there was seen a direct positive and significant relationship between familiarity with computer and Meta cognitive awareness of general strategies of reading e-texts, Rozomjod and saderi (2009), found a significant relationship between multiple intelligence and learning vocabulary. In addition the results showed that Meta cognitive strategies, memory and social strategies had a significant relationship with grounds of multiple intelligence.

Aghazadeh (1998), showed that if the individual could have awareness of cognitive process and what passes in his mind, he can have the most favorite form of information transfer. Abdoos (2001), showed that educating Meta cognitive strategies leads to increase creativity.In addition, there is a relationship between Meta cognitive skills and creativity. Ghorchian (1999), showed that applying Metacognitive strategies in class room brings about the ground of scientific engagement emotional joy, constructiveness, creativity and social selfresponsibility and increases self-confidence. Hashemi and Hemati (2008), comparing application of motivational, attitude, time management, emotional peace, and concentration, information processing among successful and unsuccessful students concluded that there is a significant relationship between these students in using the skills and successful students used the learning strategies more than unsuccessful ones. Comprehension and reading speed can be predicted by eye movements (Skoog, 2003) 


\section{Methodology}

a) Sample population: the sample population consisted of all first grade girl students in academic year of 2011 in high schools of zone 1 and 2, respectively.

b) Sampling: In this research, all the samples of research were 60 students, 5 of them were not interested in participating in cognitive group. There was transferred to another school and 2 migrated strategy training group. Therefore, the sample reduced to 50, 25 in cognitive and 25 in control group. The multi stage cluster sampling was used. Research procedure this is a semi-experimental research in which there is no possibility of simultaneous. The Random selection and control and can control some internal validity criteria [Delavar, 1995].the most common semi experimental research is pretest and posttest plan with control group (without random selection).

1) Pretest of reading speed, memorization and comprehension.

Measurement tools

1) Chronometer: A big clock was used in the class to measure the reading speed.

2) The course content of test; 8 course texts the pretest and posttest of which had been prepared from the Persian literature and biology of the high school first grade (code A) and (code B) respectively with differ nature were chosen. Two of each for course contents was easy and difficult, respectively, for Persian literature and biology, with 30 questions for each text had 30 questions, 15of which measured memorization questions and 15 comprehensions questions. The criterion of ease or difficulty of test was:

a) Information from experienced teachers and experts based on the course structure and - academic performance

- polling from students other than sample group

Scoring: each test had 30 questions from the textbook, with 15 scores for memorization and 15 for comprehension

Test validity; the table of characteristics of test plan was used to make assured of content validity along with the opinions of experts to make sure of validity of content. The experts believed that the questions represented the content and aims of research. 
Reliability of test: the reliability of a measurement tool is dependent on the stability degree which the tool measure the subject with (Razavi. et al,1960)For validity of the test, bisection method and kuder-Richardson test were used. MesrAbadi and other the validity of the questionnaire in 2001 and 2014, respectively, as reported in (table 1).

Table 1: reliability coefficient of

\begin{tabular}{cllll}
\hline Researcher & Difficult biology & Easy biology & $\begin{array}{l}\text { Difficult } \\
\text { literature }\end{array}$ & $\begin{array}{l}\text { Easy } \\
\text { literature }\end{array}$ \\
\hline MesrAbadi 2001 & 0.97 & 0.95 & 0.95 & 0.94 \\
\hline 2014 & 0.81 & 0.89 & 0.82 & 0.81 \\
\hline
\end{tabular}

Execution method: first, pretest was done for two groups. The students read the texts and recorded the time spend. Then, the students answered 30 questions of 4 choices extracted from the texts to transfer their memorization and comprehension. This general trend of testing was used in both stages of testing (pretest-posttest). In each stage of measurement, 4 testes were given to subjects (pretest and posttest). After completion of pretests, the cognitive underwent a training program in 14 sessions of 45 minutes each and the control group received training about learning strategies and reading speed. The cognitive learning strategies included (review, expansion, organization and ordering) and reading speed included (reading aloud, lip reading, silent reading and eye reading). The both groups were tested after the completion of training.

Table 2: Teaching Meta cognitive learning strategies

\section{.1-Diterminig the aim of stady}

\begin{tabular}{|c|c|c|}
\hline Planning strategies & $\begin{array}{c}\begin{array}{c}\text { Survalance and control } \\
\text { strategies }\end{array} \\
\end{array}$ & Organizing strategies \\
\hline $\begin{array}{l}\text { 2-Prediching reawrid time } \\
\text { for stady }\end{array}$ & $\begin{array}{l}\text { 1-Evaluation of prograss } \\
\text { 2-Spervision on attention }\end{array}$ & 1-Modifying stady speed \\
\hline $\begin{array}{l}\text { 3-Determining stady } \\
\text { speed } \\
\text { 4-Anatyzeng how to } \\
\text { address the issue } \\
\text { 5-Selechhing learning } \\
\text { strategies }\end{array}$ & $\begin{array}{l}\text { 3-Aslang queshens during } \\
\text { stady and learning } \\
\text { 4-Controlling hime and } \\
\text { speed of stady }\end{array}$ & $\begin{array}{l}\text { 2-Correchry or ehanying cognihive } \\
\text { strategies }\end{array}$ \\
\hline
\end{tabular}

\section{Results}

Table 3,4 and 5 report the descriptive characteristics of reading speed, memorization of texts and comprehension, easy or difficult. 


\begin{tabular}{|c|c|c|c|c|c|}
\hline \multirow{2}{*}{ Variable } & \multirow{2}{*}{ Groups } & \multicolumn{2}{|c|}{ Pretest } & \multicolumn{2}{|c|}{ Post test } \\
\hline & & mean & SD & Mean & SD \\
\hline \multirow{2}{*}{$\begin{array}{c}\text { Reading speed } \\
\text { of easy } \\
\text { literature }\end{array}$} & Test & 19.79 & 1.98 & 15.63 & 2.88 \\
\hline & Control & 23.48 & 2.62 & 24.84 & 4.53 \\
\hline \multirow{2}{*}{$\begin{array}{c}\text { Reading speed } \\
\text { of Difficult } \\
\text { literature }\end{array}$} & Test & 21.83 & 1.86 & 15.54 & 2.89 \\
\hline & Control & 24.60 & 3.08 & 23.84 & 2.49 \\
\hline \multirow{2}{*}{$\begin{array}{c}\text { Reading speed } \\
\text { of Easy } \\
\text { biology }\end{array}$} & Test & 20.83 & 3.87 & 18.67 & 2.18 \\
\hline & Control & 29.28 & 3.66 & 26.26 & 4.37 \\
\hline \multirow{2}{*}{$\begin{array}{l}\text { Reading speed } \\
\text { of Difficult } \\
\text { biology }\end{array}$} & Test & 35.13 & 3.78 & 21.48 & 1.56 \\
\hline & Control & 33.56 & 3.53 & 31.26 & 3.32 \\
\hline
\end{tabular}

Table 3: descriptive indices of reading speed for easy and difficult courses

Table 4: descriptive indices of memorization of easy and difficult courses

\begin{tabular}{cccccc}
\hline \multirow{2}{*}{ Variable } & Groups & \multicolumn{2}{c}{ Pretest } & \multicolumn{2}{c}{ Post test } \\
\cline { 2 - 6 } & Test & 8.71 & 1.49 & 13.67 & SD \\
\hline \multirow{2}{\text{Memorization}}{$\begin{array}{c}\text { of easy } \\
\text { literature }\end{array}$} & Control & 8.38 & 1.93 & 8.16 & 3.22 \\
\hline $\begin{array}{c}\text { Memorization } \\
\text { of Difficult } \\
\text { literature }\end{array}$ & Test & 7.87 & 2.25 & 10.33 & 2.14 \\
\cline { 2 - 6 } & Control & 7.12 & 2.58 & 5.36 & 2.69 \\
\hline $\begin{array}{c}\text { Memorization } \\
\text { of Easy } \\
\text { biology }\end{array}$ & Test & 6.29 & 1.87 & 13.00 & 2.10 \\
\cline { 2 - 6 } & Control & 5.84 & 2.39 & 5.80 & 2.10 \\
\hline $\begin{array}{c}\text { Memorization } \\
\text { of Difficult } \\
\text { biology }\end{array}$ & Test & 5.83 & 2.04 & 12.50 & 1.62 \\
\cline { 2 - 6 } & Control & 5.36 & 2.69 & 5.16 & 3.02 \\
\hline
\end{tabular}

Table 5: descriptive indices of comprehension for easy and difficult courses

\begin{tabular}{cccccc}
\hline Variable & Groups & \multicolumn{2}{c}{ Pretest } & \multicolumn{2}{c}{ Post test } \\
\cline { 2 - 5 } & mean & SD & mean & SD \\
\hline \multirow{2}{*}{$\begin{array}{c}\text { Reading speed } \\
\text { of easy } \\
\text { literature }\end{array}$} & Control & 9.58 & 2.83 & 13.08 & 1.35 \\
\hline & Test & 7.79 & 1.54 & 8 & 2.45 \\
\hline $\begin{array}{c}\text { Reading speed } \\
\text { of Difficult } \\
\text { literature }\end{array}$ & Control & 7.16 & 2.02 & 13.21 & 1.77 \\
\hline $\begin{array}{c}\text { Reading speed } \\
\text { of Easy biology }\end{array}$ & Test & 6.63 & 2.25 & 6.44 & 2.36 \\
\hline $\begin{array}{c}\text { Reading speed } \\
\text { of Difficult } \\
\text { biology }\end{array}$ & Test & 6.36 & 2.37 & 12.92 & 1.35 \\
\cline { 2 - 6 } & Control & 6.64 & 1.63 & 5.96 & 1.99 \\
\hline
\end{tabular}


In the investigation of hypotheses of covariance analysis i.e. normality of dependent variable, homogeneity of regression line slope, the existence of linear relationship between auxiliary random variable (pretest) and dependent variable (post-text) and equality of variances, it was found that two hypotheses of nonlinearity and homogeneity of regression line slope do not hold and the conditions of using multivariable covariance analysis test is not met. Therefore, the differentiation scores (the differences between scores of (posttest and pretest) were used to balance the effects of pretest and remove the primary differences of subjects in control and test groups. MANOVA was used for differentiation scores of memorization, comprehension, and reading speed of easy and difficult courses, as a tool for the conditions of more than one dependent variable [Adelaide \& Pexman, 2001 ]. in the present research to reduce the first type error, Bonferroni correction, was divided by the number of dependent variables and the significance of 0.025 was considered. $(0.05 / 12=0.0041)$ Dependent variables have collinear and significant relationship while there is not multiple nonlinearity among the variable pairs. Therefore one of the main assumptions of multivariable variance analysis. As the variables of memorization, comprehension reading speed of easy and difficult courses are interrelated, their correlation rate is remarkable. In addition, other conditions of homogeneity of variance-covariance matrices with box test and Simonov's distribution normality hold. (Table 5) reports the summary of multivariable variance analysis for differentiation scores of memorization, comprehension and reading speed of easy and difficult courses.

Table 6: summary of multivariable variance analysis for differentiation scores of memorization, comprehension and reading speed in easy and difficult literature and biology

\begin{tabular}{cccccc}
\hline $\begin{array}{c}\text { Statistical } \\
\text { power }\end{array}$ & $\eta^{2}$ & Sig. & F & d.f & Test \\
\hline 1 & 0.932 & $\mathbf{P}<\mathbf{0 . 0 0 0 1}$ & 40.79 & 12,36 & Test of Pilli's Trace \\
\hline 1 & 0.932 & $\mathbf{P}<\mathbf{0 . 0 0 0 1}$ & 40.79 & 12,36 & Test of Wilks Lambda \\
\hline 1 & 0.932 & $\mathbf{P}<\mathbf{0 . 0 0 0 1}$ & 40.79 & 12,36 & Test of Hoteling's Trace \\
\hline 1 & 0.932 & $\mathbf{P}<\mathbf{0 . 0 0 0 1}$ & 40.79 & 12,36 & $\begin{array}{c}\text { The test of Roy's Largest } \\
\text { root }\end{array}$ \\
\hline
\end{tabular}

The result of (table 6) show that there is a significant different between education level (cognitive versus lack of education) in the vanables of $\mathrm{m}, \mathrm{c}, \mathrm{rs}[\mathrm{F}(12,36)=$ 40/799, $\mathrm{P}<0 / 0001,=0 / 932]$. Therefore, educating cognitive learning strategies had significant effect on $\mathrm{m}, \mathrm{c}$, and rs. Of easy and difficult courses. 


\begin{tabular}{|c|c|c|c|c|c|c|c|}
\hline $\begin{array}{l}\text { Statistic } \\
\text { al power }\end{array}$ & $\eta^{2}$ & $P$ & $\mathrm{~F}$ & M.S & d.f & S.S & Dependent Variable \\
\hline \multirow[t]{2}{*}{0.999} & \multirow[t]{2}{*}{0.361} & \multirow[t]{2}{*}{$\mathrm{P}<0.0001$} & \multirow[t]{2}{*}{26.510} & 374.009 & 1 & 374.009 & \multirow{2}{*}{$\begin{array}{l}\text { Reading speed of } \\
\text { easy literature } \\
\text { Error }\end{array}$} \\
\hline & & & & 14.108 & 47 & 663.093 & \\
\hline \multirow[t]{2}{*}{1} & \multirow[t]{2}{*}{0.431} & \multirow[t]{2}{*}{$\mathrm{P}<0.0001$} & \multirow[t]{2}{*}{35.539} & 374.686 & 1 & 374.686 & \multirow{2}{*}{$\begin{array}{c}\text { Reading speed of } \\
\text { Difficult literature } \\
\text { Error }\end{array}$} \\
\hline & & & & 10.543 & 47 & 495.518 & \\
\hline \multirow{2}{*}{0.950} & \multirow{2}{*}{0.224} & \multirow{2}{*}{$\mathrm{P}<0.001$} & \multirow{2}{*}{13.559} & 271.450 & 1 & 271.450 & \multirow{2}{*}{$\begin{array}{l}\text { Reading speed of } \\
\text { Easy biology } \\
\text { Error }\end{array}$} \\
\hline & & & & 20.20 & 47 & 940.958 & \\
\hline \multirow[t]{2}{*}{1} & \multirow[t]{2}{*}{0.716} & \multirow{2}{*}{$\mathrm{P}<0.0001$} & \multirow[t]{2}{*}{118.372} & 1587.63 & 1 & 1587.63 & \multirow{2}{*}{$\begin{array}{c}\text { Reading speed of } \\
\text { Difficult biology } \\
\text { Error }\end{array}$} \\
\hline & & & & 13.412 & 47 & 630.373 & \\
\hline \multirow[t]{2}{*}{1} & \multirow[t]{2}{*}{0.563} & \multirow{2}{*}{$\mathrm{P}<0.0001$} & \multirow[t]{2}{*}{60.666} & 403.44 & 1 & 403.44 & \multirow{2}{*}{$\begin{array}{l}\text { Memorization of } \\
\text { easy literature } \\
\text { Error }\end{array}$} \\
\hline & & & & 6.65 & 47 & 312.56 & \\
\hline \multirow[t]{2}{*}{1} & \multirow[t]{2}{*}{0.543} & \multirow[t]{2}{*}{$\mathrm{P}<0.0001$} & \multirow[t]{2}{*}{55.733} & 461.127 & 1 & 461.127 & \multirow{2}{*}{$\begin{array}{c}\text { Memorization of } \\
\text { Difficult literature } \\
\text { Error }\end{array}$} \\
\hline & & & & 8.274 & 47 & 388.873 & \\
\hline \multirow[t]{2}{*}{1} & \multirow[t]{2}{*}{0.626} & $\mathrm{P}<0.0001$ & 78.819 & 548.307 & 1 & 548.307 & $\begin{array}{l}\text { Memorization of } \\
\text { Easy biology }\end{array}$ \\
\hline & & & & 6.957 & 47 & 326.958 & Error \\
\hline 1 & 0.648 & $\mathrm{P}<0.0001$ & 86.652 & 583.825 & 1 & 538.825 & $\begin{array}{l}\text { Memorization of } \\
\text { Difficult biology }\end{array}$ \\
\hline & & & & 6.738 & 47 & 316.665 & Error \\
\hline 1 & 0.474 & D $<0001$ & 42,424 & 325.817 & 1 & 325.817 & $\begin{array}{c}\text { Compression of easy } \\
\text { literature }\end{array}$ \\
\hline & & & & 7.680 & 47 & 360.959 & Error \\
\hline 0.998 & 0.339 & $\mathrm{P}<00001$ & 24.123 & 217.890 & 1 & 217.890 & $\begin{array}{l}\text { Compression of } \\
\text { Difficult literature }\end{array}$ \\
\hline & & & & 9.032 & 47 & 454.518 & Error \\
\hline & & & & 557.633 & 1 & 557.633 & Compression of Easy \\
\hline 1 & 0.591 & $\mathrm{P}<0.0001$ & 67.913 & & & & biology \\
\hline & & & & 8.211 & 47 & 385.918 & Error \\
\hline & & & & 577.361 & 1 & 577.361 & Compression of \\
\hline 1 & 0.555 & $\mathrm{P}<0.0001$ & 58.667 & & & & Difficult biology \\
\hline & & & & 9.856 & 47 & 463.333 & Error \\
\hline
\end{tabular}


Table 7 summarizes the statistical analysis of one variable variance analysis for differentiation scores of dependent variables.

Table 7: the summary of one variable variance analysis for differentiation scores of dependent variables of research difficult literature $[\mathrm{F}(1,47)=60 / 666, \mathrm{P}<0 / 0001$, = 0/563] were obtained which show educating cognitive learning strategies influences the memorization of easy and difficult literature significantly. For the memorization of easy biology $[\mathrm{F}(1,47)=55 / 733, \mathrm{P}<0 / 0001,=0 / 543]$ and difficult biology $[\mathrm{F}(1,47)=78 / 819, \mathrm{P}<0 / 0001,=0 / 626]$ were obtained which show educating cognitive learning strategies influences the memorization of easy and difficult biology significantly. For the comprehension of easy literature $[\mathrm{F}(1,47)=$ $86 / 652, \mathrm{P}<0 / 002,=0 / 648]$ and difficult literature $[\mathrm{F}(1,47)=42 / 424, \mathrm{P}<0 / 001,=$ 0/474] were obtained which show educating cognitive learning strategies influences the comprehension of easy and difficult literature significantly. For the comprehension of easy biology $[\mathrm{F}(1,47)=24 / 123, \mathrm{P}<0 / 0001,=0 / 339]$ and difficult biology $[\mathrm{F}(1,47)=67 / 913, \mathrm{P}<0 / 0001,=0 / 591]$ were obtained which show educating cognitive learning strategies influence the comprehension of easy and difficult biology significantly. For reading speed of difficult biology. $[\mathrm{F}(1,47)$ $=58 / 587, \mathrm{P}<0 / 047,=0 / 555]$ were obtained which show educating cognitive strategies does not influence the reading speed of difficult biology.

\section{Discussion}

The analysis of data from memorization test in easy and difficult literature and biology in pre-and posttest stages show that there is a significant difference. The efficacy of teaching meta Meta cognitive learning strategies on memorization has been confirmed by authors such as Androd, Hiuobard,Wilkson(1990);Koars,Fiuor,Bavers,Salas(2004);Alovin,Maklaren RolKodinger(2006);Nijohs,Segroz,Gijelser,(2008);Lee,(2008)Lam(2009);Cheng(2 009);Marandi,Mokhtarniya,(2010);Sone(2010);Jing,Sharping(2011)has been reported and confirmed. These findings are confirmed with those of researchers in Iran such as TavakoliZadeh and Ebrahimi, (2011); Alibakhshi \& Zare (2010); Abdkhoday\& Ghafari (2010); Abedini (2009); Moeini kia \&Nokhostin doost (2009); Seyf \& Atar (2009); Pishavard (2001);Abdos (2001) has been reported and support the findings of our research.

Meta cognition is a method to make learning significant and is the skill of thinking and person's ability to think about his own thinking process. This knowledge helps the students to supervise the progress of learning and its efficacy, retrieve the information in his memory and promote his recitation.

Memorization involves attention to aim and attention is the starting point of memory process. Meta Cognitive strategies help the students to combine the fresh information with the old information and restore it in the memory. What is stored in long-term memory is never lost. Therefore, the students can increase their 
memorization by applying meta cognitive strategies in retrieving information and improve their own academic skills.

As the means cores of memorization pretest of easy and difficult literature and biology were compared in both test and control groups with ANOVA and it was concluded that there is significant relationship between two groups. Teaching meta cognitive learning strategies increases the students' memorization in literature and biology. On the other hand, controlling field of study, sex, age of subjects increases the validity of this conclusion.

The analysis of data from the test of comprehension in literature and biology shows a significant difference. The efficacy of teaching meta cognitive learning strategies on memorization has been confirmed by authors such as Ness and Middleton(2012); Lee (2008); Lam (2009); and Aershos (2010); Dong, Ling, Jovang (2010); Rahimi, Katal(2012); Gerami, Madani (2011); Son(2010);Hanter, Lindez(2005)has been reported and confirmed.

These findings are confirmed by those of other researchers in Iran such as Haghani and Khadivzadeh (2009); AliBakhshi \& Zare (2010); Karshaki (2010); Abdkhoday \& Ghafari (2010) ;Aghazade (1998); Seyf \& Atar (2009); Maher\&Bahari (2007)has been reported and support the findings of our research.

Comprehension is one of the basic academic skills which promote academic achievement. The students who understand the content better have more skills in responding the questions and present better progress. Students are usually aware of learning strategies but due to lack of supervision on learning process fall in to trouble in comprehension and cannot use them to retrieve the information. Meta cognitive strategies help the students to control and supervise the learning process and organize their study.

The analysis of data from test of reading speed in As the means cores of reading speed pretest of easy and difficult literature and biology were compared in both test and control groups with ANOVA and it was concluded that there is significant relationship between two groups. Teaching Metacognitive learning strategies increases the students' reading speed in literature and biology.

The efficacy of teaching meta cognitive learning strategies on reading speed has been confirmed by authors such as Koars, Fiuor, Bavers, Salas(2004);Lee,(2008); Sone (2010) has been reported and support the findings of our research. To explain this, it can be said that learning includes reading, retaining and reciting. The first condition of learning is reading accurately. Implementing meta cognition strategies and using the principles of fast reading can help to increase the speed of reading properly without having any effect on learning and comprehending by students. 
As the means cores of reading speed pretest of easy and difficult literature and biology were compared in both test and control groups with ANOVA and it was concluded that there is significant relationship between two groups. Teaching Metacognitive learning strategies increases the students' reading speed in literature and biology. On the other hand, controlling field of study, sex, age of subjects increases the validity of this conclusion.

Learning includes reading, story and reciting. The first requirement of learning is reading correctly. Applying Metacognitive strategies can help the students to increase their reading speed. As the means cores of memorization pretest of easy and difficult literature and biology were compared in both test and control groups with ANOVA and it was concluded that there is no significant relationship between two groups. Teaching Metacognitive learning strategies increases the students' memorization in literature and biology. The analysis of data from the test of reading speed in difficult biology in pretest and posttest stages shows no significant difference between two groups. To increase the reading speed along with comprehension the students need to spend a lot of time while special terminology and time limitation can play a role in not increasing speed of study. Base on Seyf and Shaghashi (2009), the important factor in study speed is processing speed of information cognitively rot the eye movement on the lines. Also, forcing individual to increase speed though increasing eye movement on words leads to decrease understanding the content. The results of the researches show lack of relationship between the speed and understanding. In this research, there was not seen any significant relationship between educating cognitive strategies and increase of reading speed in easy and difficult biology. The findings of the research showed that educating cognitive learning strategies influence the student's performance in literature and biology (easy and difficult significantly).

\section{References and notes:}

Abedini, Yasaman. (2009).Model of structure scholastic achievement in math student, role of learning sterategy in realated to scholastic achievement. Letter season .education novel.12, 24 32.

Abdkhodaei,Mohammad saied.Ghafari,Abolfazl(2010).Investigate amount use student of study and learning skill and realated to their scholastic background .educational and psychology studies university of Ferdousi Mashhad.2, (11), 210-226.

Abdus,Mitra(2001)the effect of cognitive and metacognitive teaching on the gnwth of self-coring in third 3high school students, Tehran,masters thesis, Alzahra university

Anderson, N. J. (2002). The role of metacagnition in second language teaching and learning. Brigham Young University Eric Digest.

Aleven, V. McLaern, B. Roll, I., \& Koedinger, K. (2006). Toward Metacognitive Tutoring: A Model of Help Seeking with a Cognitive Tutor. International Journal of Artificial Intelligence in Education. Computer Science andArtificial Intelligence. Vol. 16, Number 2/2006. pp. 101-128. 
Adlayd,A,M,Nickel,Pecksman,P,M(1999).Applied manual Provide and monitor statistics tables in behavior researches. Translated by Homan, Heydar Ali and Asgari, Ali(2009).Tehran Publishing Samt.

Aghazadeh,Moharam(1998).A;Look to metacognition theory and education application it. Hamshahri press, September,No 1328.

Alibakhshi,SeyedehZahra.Zare,Hossein.(2010).Effectiveness training self-regulated learning study skill on Scholastic achivment student .letter season applied psychology,2,4,(15),69-80.

Bashavard,Simin(2001)the effect of teaching cognitive and metacognitive strategies on problem solving performance of matematies in mentally retarded students,masters thesis ,Tehran university.

BruceuW.T., Dennis, A. A., and Dennis R.S. (2007). Learning and Motivation strategies: You're Guide to success. Pearson Education.

Cheng.C.T.Cheng.I(2009).Investigation of foreign language vocabulary learning strategies by Taiwan's technical university students. International Journal of Teaching and Studies. 5, 2

Cuevas, H. M., Fiore, S. M., Bowers, C. A., \& Salas, E. (2004). Using Guided Learner-Generated Instructional Strategies to Transform Learning into a Constructive Cognitive and Metacognitive Activity.

Clipa, O., Ignat, A. A., \& Rusu, P. (2011). Relations of self-assessment accuracy with motivation level and metacognition abilities in pre-service teacher training. Faculty of Science of Education, "Stefan cel Mare" University, str. Universitatii, nr. 13, SUCEAVA, 720229. ROMANIA. Procedia - Social andBehavioral Sciences 30 (2011). 883-888.

More.J.\&Press,D.(2001).Metacognition and reflection increasing awareness to improve learning .Journal of Experinmental ChildPsychology,43.129.148

Delavar,Ali.(1995).Theorical basic and research science in social science Tehran, Roshd published.

Dong, Y., Lim, K. C., Zhu, L., \& Wang, Y. (2010). Research on mother

tongue,s learning strategies of pupils in Singapore. Procedia - Social and BehavioralSciences). $572-575$.

Ersozlu, Z. N. (2010). Determining of the student teachers, learning and studying strategies. University of Gaziosmanpasa, Department of Education.

Ghorchian,Nadergholi.Fatalikhani,Manouchehri,Mousavi,Sayed mokhtar,falegh,Davod(1999)lerninge theories and metacognitve in learning efficiency process,second edtion.Tehran.Tarbiat.

Gourami, M. H., \& Madani, S. (2011). International Conference on Education and Educational Psychology (ICEEPSY 2011). Language Learning Strategy Used by Successful and Unsuccessful Iranian EFL Students. Procedia - Social andBehavioral Sciences 29 $1567-1576$.

Hae.D.S.(2001).The effecte of metacognition strategy instruction types and lous of control on the elaborative learning strategy utilization in korean elementary school students.American Educational ResearchJournal .34.174.206

Haghani,Fariba.Khadivezadeh,Talaat.(2009).effect cours training workshope learning and study skills and learning and study sterategy of shining aptitude. Magazine Iran education in medcin science, $9,(1), 31-40$.

Hashemi,Ahmad.Hemmati,Abouzar.(2008).compare amount to apply learning sterategy by successful and unsuccessful student.Andishe letter season.3,(2)25-31.

Hong, Eunsoo. Peng, Yong. \& Rowell, L, L.(2009).Homework self- regulation: grade, gender, achievement- level differences. Journal of Educational Psychology, Volume 19, issue2, page269-276.

Jiang.x,sharpling.G(2011)The impact of Assessment change language learning strategies : The views of a small group of chinesese graduate student studyingin the UK. . Procedi

Lam, W. (2009). Examining the effects of metacognitive strategy instruction on ESL group discussions: A synthesis of approaches. Language Teaching Research. Vol. 13 no. 2 129-150

Lavasaniu,M, Fereshteh,F(2011). Language learning strategies and suggested model in adultsprocesses of learning second languageProcedia Social and Behavioral Sciences 15 (2011) 191-197 
Lee.K.(2008)The investigation of EFLlearning strateges and strategg awareness. Asim EFL journal .volum 10.Issue 1 .

Lan, W. \& Skoog, G. (2003). The relationship between high school student's motivation and metacognition factors in science learning. Journal of Experimental Education, 62, 319-339.

Marcheschi.\& pallidino \& paola.(2000). The relation between metacognition and depressive symptoms in preadolescents with learning disabilities .Learning disabilitiosResearch \&practice.2000.vol.15.412.157.

MesrAbadi,Javad.(2001). Effectiveness training learning sterategy on speed reading and comperehensive student.M.A.Thesise .Tehran,Allameh Tabatabayi university.

Moeinikia,Mahdi.Nokhostindoost,Asghar.(2009).realated learning sterategy of self-regulation and motivation sterategy for learninig and scholastics performance student university Azad Ardebil.science and research in educational science.23.85-100.

Marandi.S,mokhtariyan.SH.(2010)Reeading strateges in Electoronic enviorment.Iranian EFLjornal .vol 6.issue.165-192

Ness, B. M., \& Middleton, M. J. (2012). A Framework for Implementing Individualized SelfRegulated Learning Strategies in the Classroom. Intervention in school and Clinic May. Vol. 47 no. 5 267-275.

Nijhuis .J \& Segers ,M. \& Gijselaers. W. (2008).The extent of variability in learning strategies and students'Perceptions of the learning environment I Learning and nstruction 18 P: 121 134Naimie, Z., Abuzaid, R., Siraj, S., Shagholi, R., \& Hejaili, H. (2010). Do you know where I can find the new center which is called " Cognitive styles and language learning strategies link"? Procedia Social and Behavioral Sciences 2 497-500

Nor Ersozlu.Z,(2010).Detemininig of the Student teacher Learninig and Studying Strategies. Procedie social and Behavioral sciences 2(2010)5147-5151

Rozmgod.S.A,Sasaleragard.R,sodri.M(2009).The investigation of the relationship between multiple intelligences, learning vocabulary learning

Rahimi, M., \& Katal, M. (2012). Metacognitive strategies awareness and success in learning English as a foreign: an overview. English Department, Faculty of Humanities, Shahid Rajaee Teacher Training University, Lavizan, Tehran, 1678815811, Iran. Procedia - Social and Behavioral Sciences 31 . 73-81.

Seyf,AliAkbar.(2007).Assessment,process and produce learning ,old and new method .Tehran,Doran published.

Seyf,AliAkbar.Atarkhameneh ,Fatemeh.(2009).effect training learning sterategy and meta cognition study on scholastic achievement motivation of student. Letter research educational studies,3,9(2);56-74.

Seyf,AliAkbar.Sheghaghi,Farhad.(2009).effect training study and learning sterategy on amount learning student of Payamenoor university.Peyk noor3,2,16.

Shirey.larkin.(2000).How can we discem metacognition in year one children from interactions between students and teacher school of eduation .Elementary School Journal .92.513.555.

Santrock,J.w.(2008). Information processing. A topical approach to life span development,272-275. New York: The Mc-Grow-Hill Companies.Inc

Shakenova.L.(2017) The Theoretical Framework of Teacher Collaboration. Khazar Journal of Humanities and social sciences. Vol 20 no.2.Baku, Azerbaijan.pp 34-48.

Son, L. K. (2010). Metacognitive control and the spacing effect. Journal of experimental psychology. Learning, Memory, and cognition. Vol. 36 no. 1. (January 2010). pp. 255-262.

Tavakolizadeh,Jahanshir.Ebrahimi Gavam abadi, Soghra(2011).Study effectiveness training learning sterategy of self-regulation on mental health second grade guidance school boy student in Mashhad. Magazine principal mental health .13,(2). 250-259

Wolters. C.A.(2004). Advancing achievement goal theory : Usinggoal . structures and goal orientations to predict students motivation . cognition and achievement . journal of Educational psychology.92(2)236-250 


\title{
Summary
}

\section{Meta-cognitive learning strategies: The effect of training strategies on memorizing, comprehension and the speed of reading}

\author{
Mohammad Asgari \\ Allameh Tabata'i University, Iran \\ Maryam Rafiee \\ Azad University, Hamedan Branch, Iran
}

The aim of this study was to determine the effect of Meta-cognitive learning strategies training on memorizing, comprehension and the speed of reading easy and difficult courses for the high school first grade male students of Hamadan. To do so, 60 students were chosen in random cluster sampling and were randomly replaced in two experiment and control groups. The research designed, the pre- test post-test with control group in the curry study pre-tested was done for both group by using research-made academic achievement test that reliability and validity of it was confirmed. The experimental group was educated with cognitive learning strategies in 14 sessions, each 45 minutes, while control group did not receive any education. Then, the post-test of research-made academic achievement was carried out. The data analysis with MANOVA for differentiation scores showed that teaching cognitive learning strategies have increased memorizing and comprehension of student in easy and difficult literature and biology at the level of, while having a significant positive affection on the reading speed in easy and difficult literature and easy biology with significant no effect on the reading speed of difficult biology.

Keywords: comprehension, Metacognitive strategies, learning strategies reading speed, memorizing on the Relationships among EFL Learners' Willingness to Communicate, Communication Apprehension, Self-Perceived Competence and Emotional Intelligence 